\title{
An Analysis of Forms and Effects of Workplace Harassments on the Female Students' during the Industrial Internship Program in the Hotel
}

\author{
Renata Kenanga Rinda ${ }^{1 *}$,Nodistya Septian Indrastana ${ }^{2}$, \\ Cholimatus Zuhro ${ }^{3}$, Vigo Dewangga ${ }^{4}$ \\ 1, 2, 3, 4 Language, Communication, and Tourism Department, Politeknik Negeri Jember, Indonesia \\ *Corresponding Author. Email: renata@polije.ac.id
}

\begin{abstract}
The gap competence between the vocational colleges' graduates and the needs of the industrial world is a crucial problem that must be minimized immediately. Dealing with the previous phenomenon, the government brings up a program called industrial internship. In line with the earlier policy, Politeknik Negeri Jember, as one of the vocational colleges, requires an industrial internship program. Various industrial places are offered to the students. One of them is in the hotel. However, during the program's implementation, the problems related to workplace harassment are faced by the students, especially the female ones. This case leads to a problematic situation. The further implication, the goal to fill the gap competence will be far from the reach. To cope with the preceding dilemma, this qualitative paper aimed to describe the forms and effects of workplace harassment experienced by female students during the industrial internship in hotels. Sixty-seven female students and graduates were involved as participants. The questionnaire was used to collect the data. Based on the analyzed data, it can be summarized that: 1) there are two forms of workplace harassment on the female students, which are direct and indirect, and 2) there are three effects of workplace harassment on the female students, which are devouring lesser moral value, having lower work performance and the changing of employment status. By briefly describing the two results, it is expected that the workplace harassment experienced by female students during the implementation of industrial internships can drag the policymaker's attention to be promptly lessened and solved.
\end{abstract}

Keywords: industrial internship, workplace harassment, hotel, gender

\section{INTRODUCTION}

It is widely known that the number of people who are now jobless is rising significantly. The impediment between the competence of vocational colleges' graduates and the needs of the industrial world becomes one of the reasons for it. The graduates have been struggling to implement the theory taught in the college into the workplace. The condition in workplace is not always the same with the things they have learned in the college. The Ministry of Education, Culture, Research, and Technology proposed two concepts called Link and Match and Merdeka Belajar Kampus Merdeka (MBKM) to cope with the previous problem. The first concept, Link and Match, aim at increasing the collaboration between the colleges and the industrial world [1]. The college's curriculum is revised based on the requirements of the industrial world. Then, based on The Ministry of Education, Culture, Research, and Technology's regulation no 3 the year 2020 [2], the second concept, MBKM, is described as a way of learning that gives a chance to the students to take lessons outside their study program.

To implement the two previous concepts, the program called industrial internship is created. By joining the program, the students can have experience of transforming the classroom theory into practice. They also can have real experience of working and feel the atmosphere of industrial world lasted for 4 up to 6 months. Regarding on the previous benefits, the industrial internship program is considered as the best way to implement the Link and Match and MBKM [3]. 
As one of the executants of the industrial internship program, Politeknik Negeri Jember (POLIJE) requires it for all the students in eight departments. Every department can propose the industrial place where the students can follow the program. Department of Language, Communication, and Tourism that focuses its goal for creating competent graduates in the hospitality sector offers several places to the students such as hotels, travel companies, and tourism industries. Then, students can freely choose one of the offered places after consulting with the coordinator of industrial internship program. Based on the documented data, hotel becomes the most preferable place for the students of The Department of Language, Communication, and Tourism to conduct the industrial internship program. In line with the previous information, the number of graduates who work at the hotel gains the highest percentage among other places.

Nonetheless, based on the short online discussion with the students participated in the industrial internship program, another side of it that had never been discovered before was found. The students, especially the females, ever experienced of workplace harassment such as bullying. Drowning in such an atmosphere, the students felt uncomfortable. It gave effects not only on their quality of working but also their mental. When this crucial problem is not solved immediately, the goal of industrial internship would be possibly unreached. Seeing this situation, this paper aimed at describing the forms and effects of workplace harassment on the female students during their internship program in the hotel. After describing those things, it is hoped that the hidden fact would be seen by the policymakers to be promptly lessened and solved.

\section{LITERATURE REVIEW}

\subsection{The Nature of Gender}

Up to now, gender is considered a topic that still the researchers put their eyes on. The word gender is described as a social construction of identification toward men and women. Men are associated with masculinity. They are strong and rational. Opposite with men, women are justified as soft, weak, and shy. They tend to be more feminine [4]. Additionally, stated by [5], gender is accepted as the differences between men and women viewed from the role, social status, and responsibility in the society. From those previous statements, it can be understood that gender is a result of shared assumption of the society.

The practice of gendered assumption put the men's position higher than the women's. Men are believed as a more influential group of people and play a central role in society. They gain trust as a breadwinner for the family while the women stay at home to raise the children [4]. With this condition, gendered assumption gives more benefit to men and offers more disadvantages to women.
To answer the above ironic condition, the Government of Indonesia proposed regulation UU No. 7/1984. This action was inspired by the United Nations Conference conducted in 1979 about equality between men and women. However, the effect of that regulation is still far from what was expected. In all over Indonesia, the case related to harassment directed to women both physically and mentally in the house or workplace is still reported up to recent years.

\subsection{Workplace Harassment}

Workplace harassment is identified as the act of making other people becoming hurt physically or mentally. It happens in the places of work. Workplace harassment leads to an uncomfortable working situation [6]. The perpetrator of this action generally has a higher position in the office compared to the victim. The practice of workplace harassment is still commonly found [7] cited in [8]

According to [9], several groups of people have a higher probability of being the victim of workplace harassment. Those groups are women, part-time workers, young workers, and workers from the minority race. In the field of work, the number of women workers is bigger than the number of men. However, the women's domination does not guarantee them to be safe. They are still becoming the victim of workplace harassment. Then, the part-time workers and young workers are the second and the third groups that commonly become the victims of workplace harassment. It happens because of their lower position in the office compared to the other workers. Last, workers coming from minority races are also commonly detected as the target of the case.

Moreover, having a deeper discussion on workplace harassment, the form of it is divided into two which are direct and indirect [8]. Direct workplace harassment happens when the perpetrator and victim are physically present in the same place. The examples of direct workplace harassment are disturbing, hitting, and making fun of the victim. The previous actions can be done both verbally and physically. Then, the second form is indirect workplace harassment. The action only can be done verbally since the perpetrator and victim stay in two different locations. It is mediated by communications tools such as cell phones and social media applications. The examples of indirect workplace harassment are abusing through negative comments and sharing the victim's personal information without any permission.

The forms of workplace harassment explained in the previous paragraphs have harmful effects on those who experience it. [10] classified it into three which are moral, work performance, and the employment status. The first effect, moral, can be observed when the victim feels to have lower self-esteem, stress, depression, and fear. Then, the second effect, which is work performance, can be observed from the lessening of 
work attendance, job satisfaction, commitment, and motivation. Last, related to the employment status, the victim of workplace harassment prefers to choose to quit the job and find the more convenient place to work.

\subsection{Previous Study}

Workplace harassment has become the center of world study. The previous statement is proved from the various findings shows by the researchers. In the year 2014, [8] involved 20 workers as the participants. The focus of the study was to find out the forms of workplace harassment in the industrial area of Gresik, East Java. The qualitative approach was used to gather the information needed. The interview became the tool of it. The results of the study show the four forms of workplace harassment that happened which covers physically, verbally, psychologically, and socially.

Conducted in the same year, [11] investigated the relationship between verbal workplace harassment and work burden on the 613 hotel workers and travel agent staff in Egypt. The approach used was quantitative with a questionnaire as the research's instrument. The study's finding highlighted a strong correlation between verbal workplace harassment and the work burden - the more verbal workplace harassment directed to workers, the more work burden experienced by them.

Having reviewed the two previous studies, the participants of the study are not specified yet. All the participants are men and women adult workers. In this study, the writers try to bring a new perspective by involving the female students in their internship program that assumed to have a bigger chance of experiencing workplace harassment. By choosing those students, it is hoped that the data gathered are more comprehensive than the previous studies ever conducted.

\section{METHODS}

To cope with the two research questions which are first, describing the forms and second, exploring the effects of workplace harassment on the female students during the implementation of industrial internship in hotel, a qualitative research design was used. Sixty-seven female students were involved in answering the questionnaire given.

There were ten questions in the form of open-ended and closed-ended on the questionnaire. They were then divided into four classifications. The first classification was formed to get the demographic data. It was stated in questions number 1 and 2 . The second group was arranged to get basic information about workplace harassment indicated in number 3 . Then, the third classification was used to answer the research question related to the forms of workplace harassment. It was stated in questions numbers 4,5 , and 6 . Next, the fourth classification was intended to answer the second research question related to the effects of workplace harassment stated in numbers 7, 8, 9, and 10. The list of questions and provided answers can be seen in Table 1 below:

Table 1. List of Questionnaire

\begin{tabular}{|c|c|c|}
\hline No & $\begin{array}{l}\text { Questions } \\
\end{array}$ & Provided Answers \\
\hline 1 & What is your name? & - \\
\hline 2 & $\begin{array}{l}\text { How old are you when joining } \\
\text { the industrial internship } \\
\text { program? }\end{array}$ & - \\
\hline 3 & $\begin{array}{l}\text { Have you ever had the } \\
\text { experience of workplace } \\
\text { harassment during your } \\
\text { internship program? }\end{array}$ & $\begin{array}{ll}\text { a. } & \text { Yes } \\
\text { b. } & \text { No }\end{array}$ \\
\hline 4 & $\begin{array}{l}\text { What are forms of workplace } \\
\text { harassment that have been } \\
\text { experienced? }\end{array}$ & $\begin{array}{ll}\text { a. } & \text { Direct } \\
\text { b. } & \text { Indirect } \\
\text { c. } & \text { Direct and } \\
& \text { indirect }\end{array}$ \\
\hline 5 & $\begin{array}{l}\text { Here are examples of the action } \\
\text { of direct workplace harassment. } \\
\text { Which are the following actions } \\
\text { you have ever experienced? }\end{array}$ & $\begin{array}{ll}\text { a. } & \text { Made fun of } \\
\text { b. } & \text { Threatened } \\
\text { c. } & \text { Hit } \\
\text { d. } & \text { Physically } \\
& \text { touched } \\
\end{array}$ \\
\hline 6 & $\begin{array}{l}\text { Here are examples of the action } \\
\text { of indirect workplace } \\
\text { harassment. Which are the } \\
\text { following actions you have ever } \\
\text { experienced? }\end{array}$ & \begin{tabular}{|ll} 
a. & $\begin{array}{l}\text { Unwanted } \\
\text { massage }\end{array}$ \\
b. & $\begin{array}{l}\text { Negative } \\
\text { comment }\end{array}$ \\
c. & Sharing \\
& personal \\
& information \\
\end{tabular} \\
\hline 7 & $\begin{array}{l}\text { What are the effects of } \\
\text { workplace harassment that have } \\
\text { been experienced? }\end{array}$ & $\begin{array}{ll}\text { a. } & \text { Moral value } \\
\text { b. Work } & \text { performance } \\
\text { c. } & \text { Employment } \\
& \text { status } \\
\end{array}$ \\
\hline 8 & $\begin{array}{l}\text { Here are the examples of effects } \\
\text { of workplace harassment } \\
\text { related to moral values. Which } \\
\text { are the following actions you } \\
\text { have ever experienced? }\end{array}$ & $\begin{array}{ll}\text { a. } & \text { Lower self- } \\
& \text { esteem } \\
\text { b. } & \text { Stress } \\
\text { c. } & \text { Fear } \\
\text { d. } & \text { Fatigue } \\
\end{array}$ \\
\hline 9 & $\begin{array}{l}\text { Here are the examples of effects } \\
\text { of workplace harassment } \\
\text { related to work performance. } \\
\text { Which are the following actions } \\
\text { you have ever experienced? }\end{array}$ & \begin{tabular}{|ll} 
a. & $\begin{array}{l}\text { Lower } \\
\text { attendance }\end{array}$ \\
b. & Lower work \\
& satisfaction \\
c. & Lower \\
& commitment \\
\end{tabular} \\
\hline 10 & $\begin{array}{l}\text { Here are the examples of effects } \\
\text { of workplace harassment } \\
\text { related to employment status. } \\
\text { Which are the following actions } \\
\text { you have ever experienced? }\end{array}$ & $\begin{array}{ll}\text { a. } & \begin{array}{l}\text { Stay in the } \\
\text { same location }\end{array} \\
\text { b. } & \text { Change the } \\
\text { location }\end{array}$ \\
\hline
\end{tabular}

After collecting the results of the questionnaire, the data gathered then were inserted in Microsoft Excel. Those data then separated into four groups which are the demographic data, basic information about workplace harassment, forms of workplace harassment and the effects of workplace harassment. After that, the data from the first and the second groups were described while the data from third and fourth were analysed by comparing and contrasting them to the existed theory and previous researches. Last, all the data then were presented in the form of bar charts. 


\section{FINDINGS}

The findings of this research are divided into four parts based on the grouping of the questionnaire. The first part is for the demographic data, second part is for basic information about workplace harassment, the third part is related to the forms of workplace harassment and the fourth part is related to effects of workplace harassment.

\subsection{Demographic Data}

\subsubsection{What is your name?}

The first question on the questionnaire asked about the name of the participants. The writers protected the information so that the participants felt safe while answering the next questions.

\subsubsection{How old are you when joining the industrial internship program?}

The second question was intended to find the participants' age when they joined the industrial internship program. The answer of the participants' is presented as follows:

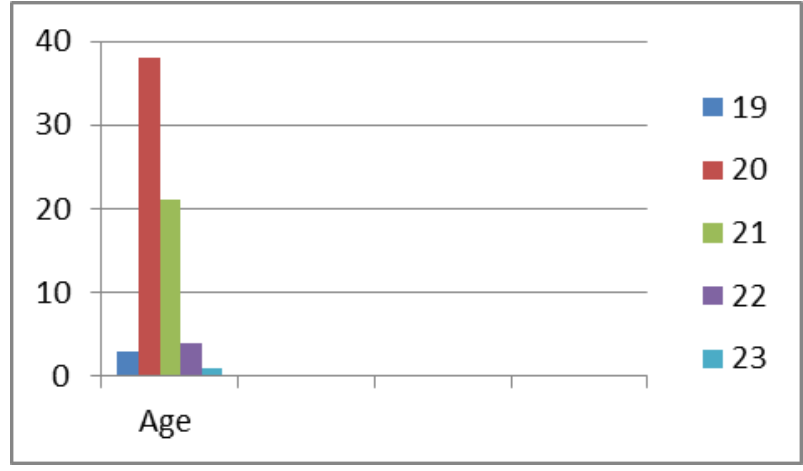

Figure 4.1 The Participants' Age

The participants' age ranged from 19 up to 23 years old. The most dominated group is the 20 years old with 38 participants. Then, the next group is 21 years old group with 21 participants. Different from the two previous groups, only 3 students are in their 19. Slightly dissimilar from it, only 4 participants are in their 22 and 1 participant in her 23.

\subsection{The Basic Information about Workplace Harassment}

\subsubsection{Have you ever had experience of workplace harassment during your internship program?}

To get the basic information about whether or not the participants had experience of workplace harassment, this question was directed to them. Participant simply could choose the "yes" or "no" to answer it. The data can be seen as follows:

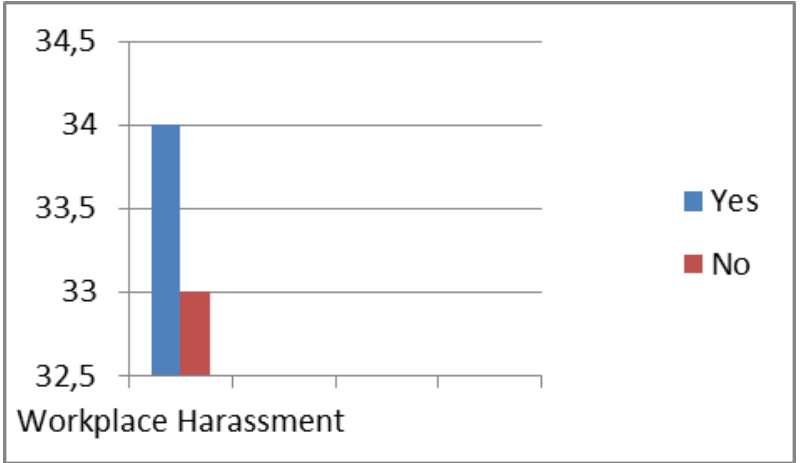

Figure 4.2 Experiences on Workplace Harassment

It can be observed from figure 4.2 that 34 participants answered "yes". It means that those students faced the problem related to workplace harassment. Then, on the other side, 33 participants never experienced the problem so that the answer "no" became their choice. From this finding, it can be seen that the number of participants that experienced workplace place harassment is quite high.

\subsection{The Forms of Workplace Harassment}

4.3.1 What are forms of workplace harassment that have been experienced?

To investigate the forms of workplace harassment, the participants of the research were instructed to click one of the three options provided which are direct workplace harassment, indirect workplace harassment, or both direct and indirect workplace harassment. The results are presented below:

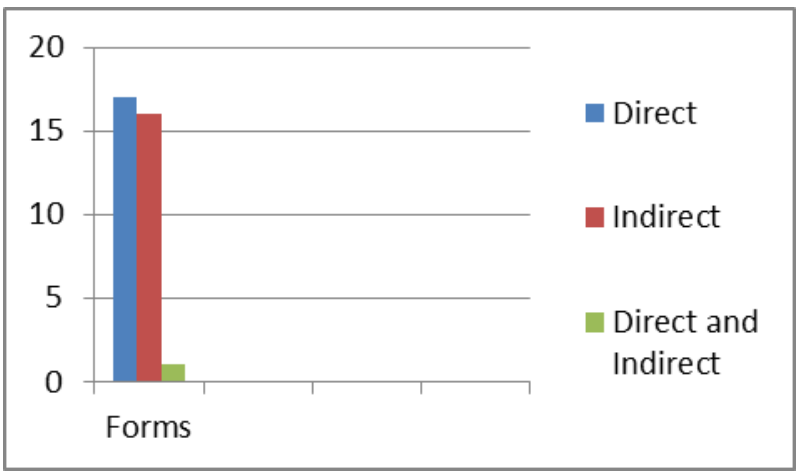

Figure 4.3 Forms of Workplace Harassment

According to figure 4.2, the two forms of workplace harassment were experienced by the participants during their industrial internship in hotel. Direct workplace harassment was faced by 17 participants. Then, the second form of workplace harassment, which is indirect, was ever faced by 16 participants. Last, both forms were experienced by 1 participant.

From the previous findings, there is no big difference between the numbers of students experienced direct or indirect workplace harassment. The existence of both forms during industrial internship in the hotel is proved from this data. 
4.3.2. Here are examples of the action of direct workplace harassment. Which are the following actions you have ever experienced?

To have further explanation about direct workplace harassment, the participants were asked to give the examples on it. Those data can be seen below:

\begin{tabular}{|r||c|}
\hline & \\
\hline & \\
\hline
\end{tabular}

Figure 4.4 the Examples of Direct Workplace Harassment

Seeing from the figure 4.3 , it can be described that the 18 participants who experienced direct workplace harassment ever received three actions related to it. Thirteen of them ever experienced of being made fun of, three were threatened, and two were physically touched without permission. Then, there was 0 participant experienced being hit.

4.3.3 Here are examples of the action of indirect workplace harassment. Which are the following actions you have ever experienced?

To have detail data of the examples of indirect workplace harassment, the question was directed to the students. The answer to it can be seen as follows:

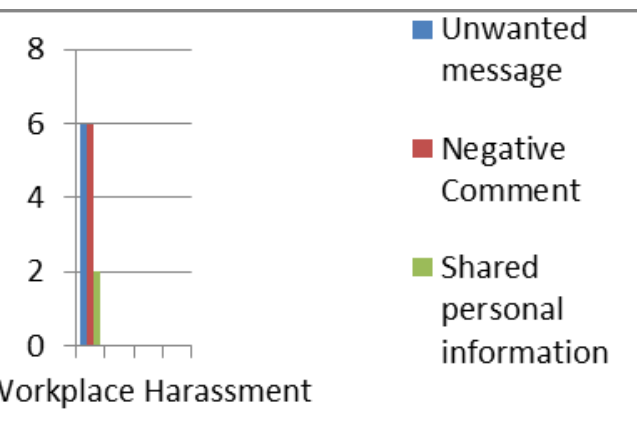

Figure 4.5 Examples of Indirect Workplace Harassment

According to figure 4.5, 6 participants experienced receiving unwanted messages through their online chatting applications such as WhatApps, 6 received negative comments on their social media, and 5 of them experienced that their personal information was being shared without permission.

\subsection{The Effects of Workplace Harassment}

4.4.1 What are the effects of workplace harassment that have been experienced?

The participants were asked to answer a question about the effects of workplace harassment. There are three provided answers, and the participants can choose more than one option. The data can be seen as follows:

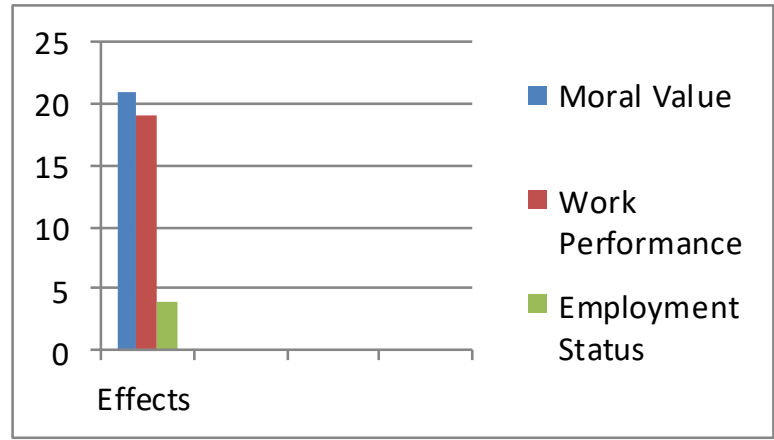

Figure 4.6 Effects Workplace Harassment

It can be observed that 21 participants chose moral value as one of the effects of workplace harassment, while 19 of them believed that work performance could be interfered with by workplace harassment. Last, only 4 of participants agreed that workplace harassment could bring an effect on their employment status

4.4.2 Here are the examples of effects of workplace harassment related to moral values. Which are the following actions you have ever experienced?

The following figure presents the effects of workplace harassment related to moral values. The participants were allowed to choose more than one option.

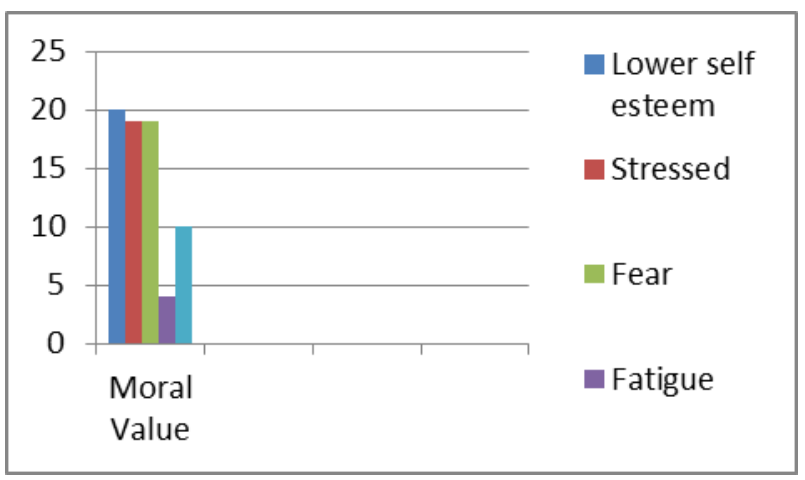

Figure 4.7 Examples of Effect related to Moral Value

Twenty students agreed that related to moral values; workplace harassment can create lower self-esteem. Then, 19 of them believed that workplace harassment could cause stress and create fear. Next, 4 participants felt fatigued because of workplace harassment. Last, 10 participants felt depressed after experiencing workplace harassment.

4.4.3 Here are the examples of effects of workplace harassment related to work performance. Which are the following actions you have ever experienced?

The following figure presents the effects of workplace harassment related to work performance. The participants were allowed to choose more than one option. 


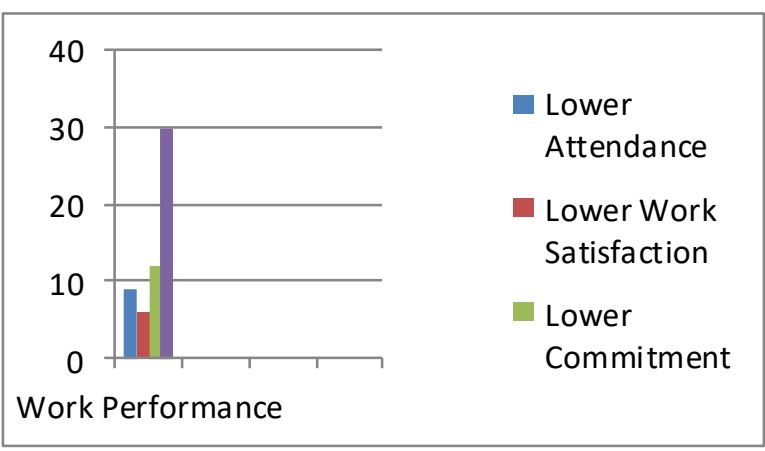

Figure 4.8 Examples of Effects on Work Performance

Related to the examples of effects of workplace harassment on work performance, 9 participants believed that it could cause lower attendance. Then, 6 of them thought that workplace harassment could cause lower work satisfaction. Additionally, 12 of them stated that lower commitment could be formed because of workplace harassment, while the 30 participants believed it could also lower the motivation.

4.4.4 Here are the examples of effects of workplace harassment related to employment status. Which are the following actions you have ever experienced?

The following figure presents the effects of workplace harassment related to employment status. The participants can only choose one of the two options offered.

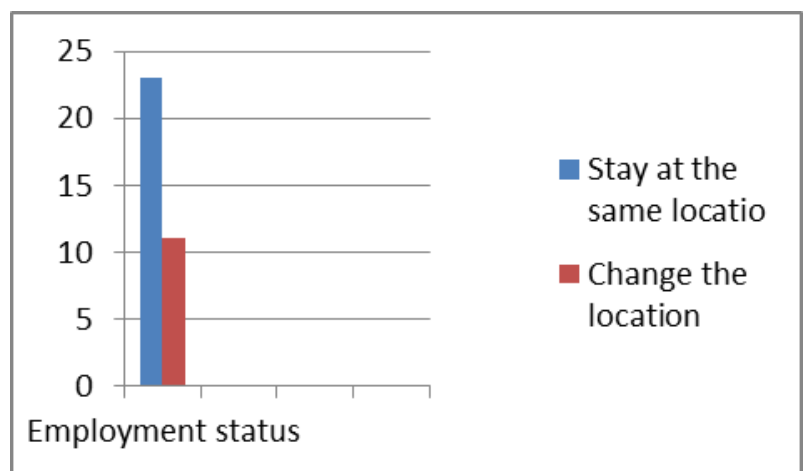

Figure 4.9 Examples of Effect related to Employment Status

Stated on the figure $4.9,23$ participants tended to choose to change the different internship locations when they were experiencing workplace harassment. In another point of view, 11 of them decided to stay at the same place.

\section{DISCUSSION}

In this part, the discussion is presented into two main categories regarding the research questions. Those are first, the forms of workplace harassment experienced by the female students during the implementation of the industrial internship program in the hotel, and second, the effects of the previous phenomenon on the female students.
According to the questionnaire given, the number of participants who experienced workplace harassment is quite high. It can be seen from questions number $3,4,5$, and 6. The previous situation happens for several reasons. According to [9] the participants of the industrial internship in the hotel which are college students are considered as a vulnerable group of workers because they are women, young, and part-time workers. First, related to their gender, all of the participants are women. It makes the bigger chance to be harassed by others compared to men students. In line with the previous statement, [12] stated in their research's finding that women from minority groups experienced the most harassment. The second reason, the participants are in their twenties that are considered as early adulthood or young workers. Compared to the workers in their middle and late adult, the young workers are also having a bigger possibility to experience workplace harassment. Then, the third reason is that the participants are in their internship program. They worked as part-time workers. They have a lower bargaining position compared to those the permanent workers. It also triggered the bigger case of workplace harassment.

Additionally, seeing from another viewpoint, workplace harassment happens not only because of the position of the victim has been mentioned before but also the type of workplace. Stated by [13], bullying and harassment frequently happen in the hospitality workplace. One of the examples of it is in the hotel. It answered why the number of participants who experienced that problem is quite high.

Then, the second research question is related to the effects of workplace harassment. It can be observed that workplace harassment gives negative effects on students. This statement is supported by the result of the questionnaire mentioned in numbers $6,7,8,9$, and 10 . Based on the results from those five questions, it can be seen that there are three types of effects of workplace harassment experienced by female students which are having lower work performance and the changing of employment status. In line with the previous result, [10] explains that workplace harassment or bullying in the workplace affects the workers in many ways. In their study, it was also mentioned that there is a connection between workplace harassment and the workers' morale and employment status. Moreover, according to the same study, because there are negative effects of workplace harassment, it is considered an unethical case that generates jeopardy to a healthy working atmosphere.

\section{CONCLUSION}

Related to the first research question, there are two forms of workplace harassment experienced of the female students during their industrial internship in the hotel which are direct and indirect. The examples of 
direct workplace harassment can be found when the students were made fun, threatened, and touched physically by other without permission. Then, related to the second research question, there are three negative effects of workplace harassment which are having lower moral value and work performance and the changing of employment status. From the previous statement, it can be summarized that this study are able to describe the existence of workplace harassment and its crucial effects. For the future study, it is expected that there will be study that propose a solution towards the existing problem so that it can be solved and prevented.

\section{AUTHORS' CONTRIBUTIONS}

The first and second writers devised the project, developed the main conceptual ideas and proof outline of the study, and worked on almost all technical details. The third and the fourth writers helped to shape the article.

\section{ACKNOWLEDGMENTS}

This study is sponsored by Pusat Penelitian dan Pengabdian kepada Masyarakat or Research and Community Service Center of Politeknik Negeri Jember.

\section{REFERENCES}

[1]. Disas, E.P., Link and Match as a Vocational Education Policy Educators Research Journal 2018. 18(1): p. 231-242.

[2]. Ministry of Education and Culture., Campus Independent Lesrning System in 15 Chapter 2. 2020, Ministry of Education and Culture Jakarta

[3]. Fitriana, O., S. Astuti, and J. Latief, Evaluation of the PKL FKIP UHAMKA Program (Evaluative Research Based on CIPP). Utilitas, 2019. 5(1): p. 7-16.

[4]. Hermawati, T., Javanese Culture and Gender Equality Journal of Mass Communication 2007. 1(1): p. 18-24.

[5]. Puspitawati, H., Gender and Family: Concepts and Realities in Indonesia. 2013, Bogor: PT IPB Press

[6]. Barling, J. and E. Kelloway, Handbook of Work Stress 2004, The Tousand Oaks, CA: Sage Publications 149-188.

[7]. Gunawan, R., S. Prihantoro, and L. Yuwanto, Causes and The Intensitivity of Workplace Bullying. Anima Indonesian Pscychology Journal, 2009. 25(1): p. 47-54.

[8]. Hidayati, N. and I. Rahayuningsih, Forms and Impact of Workplace Bullying on Factory Workers in Gresik. Journal of Psikosains, 2014. 9(2): p. 125-139.
[9]. Hoel, H. and S. Einarsen, Violence at Work in Hotels, Catering and Tourism S.A. Department, Editor. 2003, International Labour Office: Genewa

[10]. Tag-Eldeen, A., M. Barakat, and H. Dar, "Investigating the impact of workplace bullying on employees' morale, performance and turnover intentions in five-star Egyptian hotel operations. Tourism and Travelling 2017. 1(1): p. 4-13.

[11]. Demerdash, J.M.E. and H.M. Said, The Effect of Customer Verbal Aggression on Burnout Frontline Employees in HOtels and Travel Agencies: The Moderating Role of Perceived Supervisor Support Journal of Tourism and Hospitality Management 2018. 6(6): p. 291-303.

[12]. Berdahl, J.L. and C. Moore, Workplace Harassment: Double Jeopardy for Minority Women. Journal of Applied Psychology, 2006. 2(91): p. 426-436.

[13]. McMahon, L., Bullying and harassment in the workplace. International Journal of Contemporary Hospitality Management, 2000. 12(6): p. 384-387. 